\title{
(4) |EEEE
}

INDONESIA SECTION

ISBN : 978-1-7281-3016-3

PROCEEDINCS OF

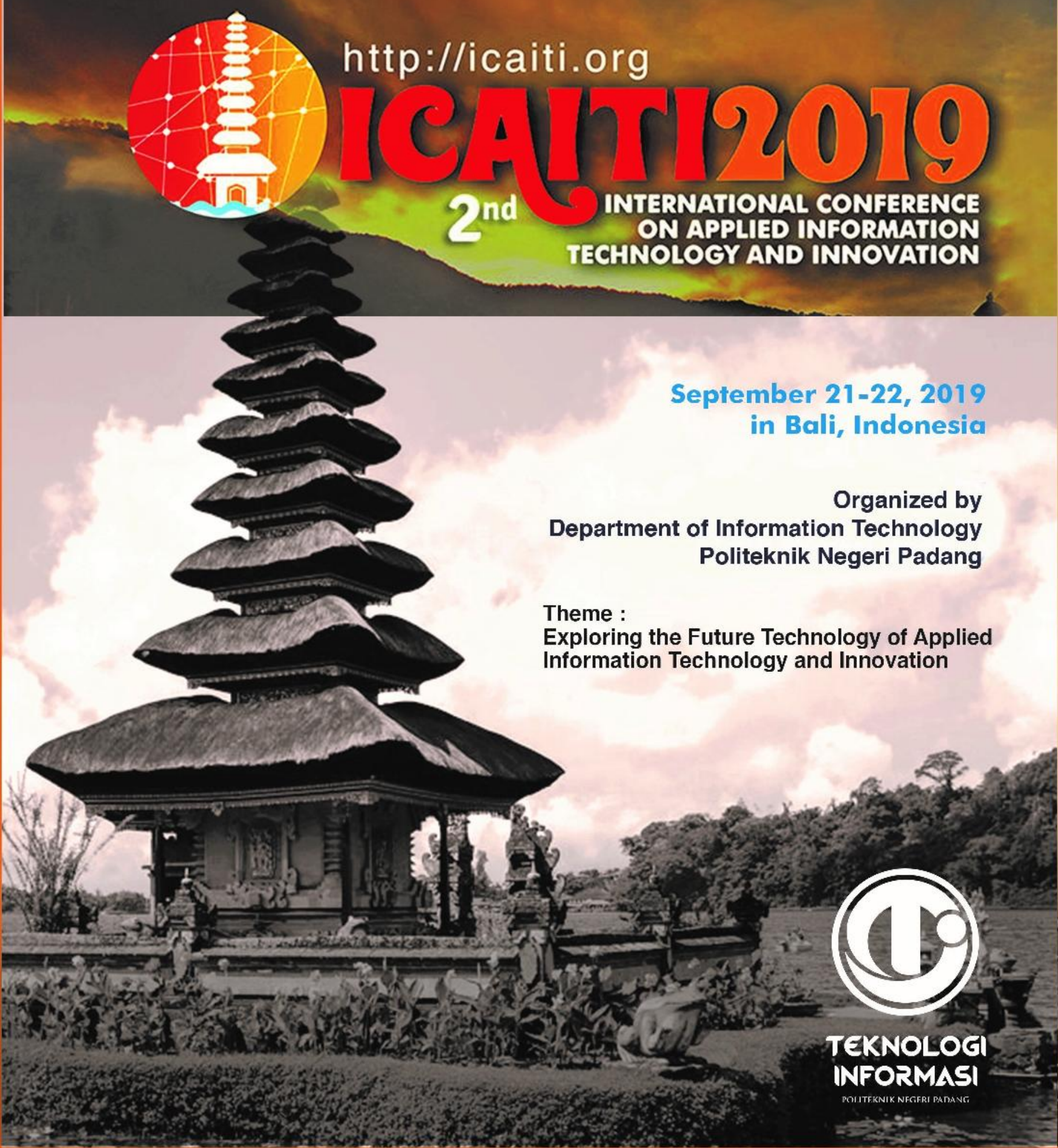




\section{ICAITI 2019 PARTNERS AND SPONSORS}

Organized by

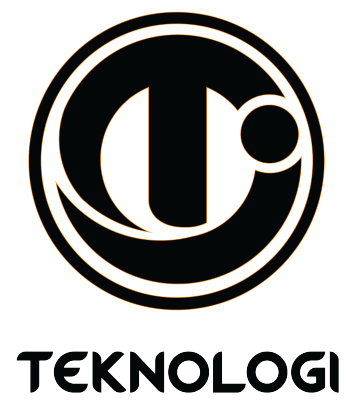

INFORMASI

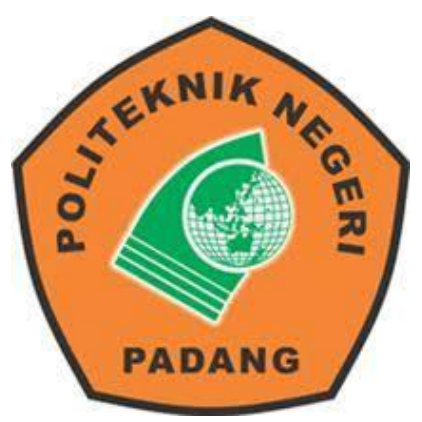

POLITEKNIK NEGERI PADANG

\section{DEPARTMENT OF INFORMATION TECHNOLOGY \\ POLITEKNIK NEGERI PADANG}

Technically Co-sponsored by

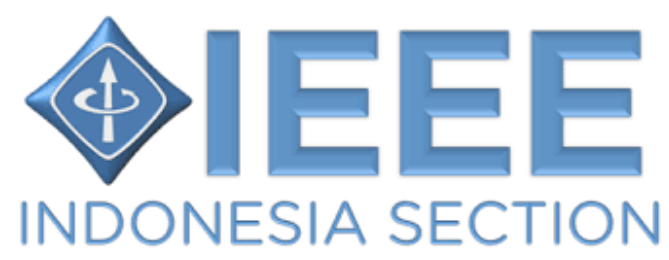




\section{Welcome Message by the General Chair}

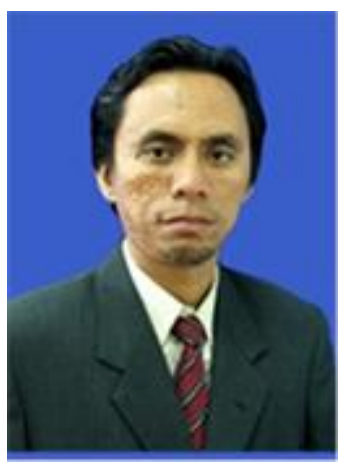

Assalamu'alaykum wrwb,

On behalf of the technical program committee (TPC), we warmly welcome you to the 2nd International Conference on Applied Information Technology and Innovation (ICAITI 2019) in Padang, Indonesia. The committee has organized exciting technical program for 2nd ICAITI with conference theme "Exploring the future technology of Applied Information Technology and Innovation ". 2nd ICAITI is the international conference organized by Politeknik Negeri Padang. As an International conference, ICAITI provides excellent platform in sharing the idea and experiences, exchange information and explore collaboration among researchers, engineers, practitioners and scholars in the field of information technology, communications, and electrical engineering.

All 120 submitted papers throughout the world went through a rigorous review process and each paper was evaluated by independent reviewers in accordance with standard blind review process. Based on the result of process, 54 papers have been selected, which constitute the acceptance rate of $45.00 \%$. 2nd ICAITI also features world-class keynote/plenary speeches and distinguish-invited speakers that reflect the current research and development trends in the aforementioned fields.

We are deeply indebted to all of our TPC members as well as our reviewers, who volunteered a considerable amount of their time and expertise to ensure a fair, rigorous, and timely review process. We are very much appreciate our keynote and invited speakers who will share their expertise in this conference. Last but not least, our sincere gratitude should be given to all authors for submitting their work to 2nd ICAITI 2019, which has allowed us to assemble a high quality technical program.

Welcome to Bali and enjoy a wonderful experience in paradise island!

With best regards

Rahmat Hidayat, ST., M.Sc. IT

General Chair 


\section{Welcome Speech \\ from The Director of Politeknik Negeri Padang}

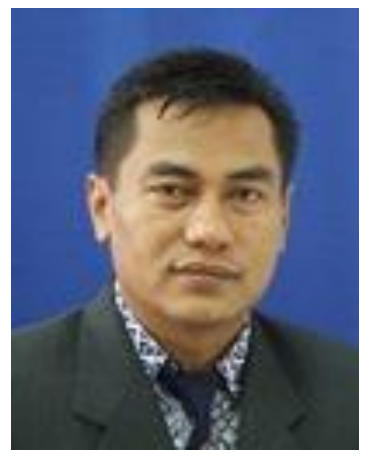

Assalamu'alaikum wr. wb,

Good morning ladies and gentlemen, our dear honorary guests and speakers.

On behalf of Politeknik Negeri Padang, I am pleased to welcome all participants to the $2^{\text {nd }}$ Conference on Applied Information Technology and Innovation (ICAITI) in Bali. We have successfully conducted the $1^{\text {st }}$ ICAITI in our hometown in Padang last year, and this year event brings ICAITI to a new horizon in Bali.

As the host, Politeknik Negeri Padang is pleased to conduct the $2^{\text {nd }}$ International Conference on Applied Information Technology and Innovation (ICAITI) 2019. As a leading higher vocational educational institution in Indonesia, Politeknik Negeri Padang strengthens its international reputation to achieve long term vision as a higher vocational education in South East Asia. This international event is part of our strategic plans toward that vision which also to strengthen our cooperation with national and international universities. We are now in the era of Industrial Revolution 4.0 where the use of information technology has penetrated every sector. Hence, by conducting this conference, we would like to gather best researchers in this field to share their knowledge and invention to the world, and to gain new perspective and plans for future research and international collaboration. This conference will be an annual event, so I would like to encourage participants to inform our fellow researchers and scholars to mark this event in their calendar. Last but not least, I also encourage our guests to enjoy the beauty of our nation and its hospitality as shown in Bali.

Warm Regards,

Surfa Yondri

Director of Politeknik Negeri Padang 


\section{COMMITEE}

\section{Steering Committee}

Prof. Kukjin Chun (Seoul National University, Korea)

Prof. Chun Che (Lance) Fung (Murdoch University, Australia)

Prof. Dr. Eng. Wisnu Jatmiko (Universitas Indonesia, Indonesia)

Dr. Kurnianingsih (Politeknik Negeri Semarang, Indonesia)

\section{Organizing Committee}

Conference Chair : Rahmat Hidayat (Politeknik Negeri Padang, Indonesia)

General Co-Chair :Indri Rahmayuni (Politeknik Negeri Padang, Indonesia)

Program Chair : Ansari Ahmar (Universitas Negeri Makasar, Indonesia)

Publication Chair: Andri Pranolo (Universitas Ahmad Dahlan, Indonesia)

Technical Program Chair : Robbi Rahim (Institut Teknologi Medan, indonesia)

Conference Treasurer: Rasyidah ( Politeknik Negeri Padang, Indonesia)

Secretariat : Aldo Erianda (Politeknik Negeri Padang, Indonesia)

Alde Alanda (Politeknik Negeri Padang, Indonesia)

\section{Technical Program Committee}

Prof. Dr. Shi-Jinn Horng, (National Taiwan University Sains \& Technology (NTUST)), Taiwan

Prof. Dr. Abderrafiaa Koukam (Université de Technologie de Belfort-Montbéliard (UTBM)),Fr

Assoc. Prof. Dr. Emanuele Menegatti, (Universita degli Studi di Padova, Padua), Italy

Assoc. Prof. Dr. Nishchal K. Verma, (Indian Institute of Technology, Kanpur), India

Dr. Arda Yunianta, ( King Abdul aziz University), Saudi Arabia

Dr. Lala Septem Riza, (Universitas Pendidikan Indonesia), Indonesia

Dr. Moslem Yousefi, (Korea university), Korea, Republic of

Dr. Danial Hooshyar, (Korea University), Korea, Republic of

Dr Ummi Rabaah Hashim, (Universiti Teknikal Malaysia Melaka), Malaysia

Dr. Abdulrazak Yahya Saleh, (Universiti Malaysia Sarawak), Malaysia

Dr.Iwan Tri Riyadi Yanto, (Universitas Ahmad Dahlan), Indonesia

Assoc. Prof. Leon A. Abdillah, (Bina Darma University), Indonesia

Dr. Genett Jimenez, (Institución Universitaria ITSA), Colombia

Dr. Leonel Hernandez (Institución Universitaria ITSA), Colombia

Prof. Tudor Palade Technical University of Cluj-Napoca

Prof. Jan-Shin Ho National Penghu University of Science and Technology

Prof. Ismail Musirin Universiti Teknologi Mara, Shah Alam

Prof. Toshiro Kodera Meisei University

Dr. Alessandro Testa Ministry of Economy and Finance

Dr. Shahreen Kasim University of Tun Hussein Onn Malaysia

Dr. Diogo Pratas University of Aveiro

Dr. Awang Pratomo Universitas Pembangunan Nasional Veteran Yogyakarta

Dr. Kamsuriah Ahmad, Universiti Kebangsaan Malaysia

Dr. Sabrina Ahmad, Universiti Teknikal Malaysia Melaka

Dr. Walid Al-Hussaibi, Southern Technical University

Dr. Haider AISabbagh, Basra University

Dr. Mohd Sanusi Azmi, Universiti Teknikal Malaysia Melaka

Dr. Noraswaliza Abdullah Kolej (Universiti Teknikal Kejuruteraan Malaysia)

Dr. Parameshachari Bidare Divakarachari Visvesvaraya Technological University

Dr. Rohayanti Hassan , Universiti Teknologi Malaysia

Dr. Mustafa Mat Deris University Tun Hussein Onn Malaysia

Dr. Lala Riza Universitas Pendidikan Indonesia

Dr. Jufriadif Na`am Universitas Putra Indonesia YPTK

Dr. Yuhefizar Politeknik Negeri Padang

Dr. Salman YussofUniversiti Tenaga Nasional

Dr. Supratman Zakir IAIN Bukittinggi

Dr. Leon Abdillah ( Bina Darma University)

Dr. Dahlan Adbullah, (Universitas Malikussaleh)

Dr. Rizal Aji , University of Indonesia

Dr. Bishanka Bhowmik , Tripura University

Dr. Dodi Devianto, Andalas University, University of Nis

Dr. Ummi Hashim , UteM

Dr. Haviluddin Haviluddin, Universitas Mulawarman 
Dr. Leonel Hernandez ITSA University

Dr. Abdul Razak Hussain Universiti Teknikal Malaysia Melaka

Dr. Ahmed Hussein University of Connecticut

Dr. Dana Indra Sensuse University of Indonesia

Dr. Darmawan Napitupulu LIPI

Dr. Shahril Parumo Universiti Teknikal Malaysia Melaka

Dr. Robbi Rahim Institut Teknologi Medan

Dr. Indri Rahmayuni Politeknik Negeri Padang

Dr. Rasyidah Rasyidah Politeknik Negeri Padang

Dr. Lizawati Salahuddin Universiti Teknikal Malaysia Melaka

Dr. Harry Santoso Universitas Indonesia

Dr. Djoko Setyohadi Universitas Atma Jaya Yogyakarta

Dr. Vasco Soares Polytechnic Institute of Castelo Branco, Instituto de

Dr. Preecha Somwang Mahanakorn University of Technology

Dr. Yance Sonatha Politeknik Negeri Padang

Dr. Endah Sudarmilah Universitas Muhammadiyah Surakarta

Dr. Muhammad Suhaizan Sulong Universiti Teknikal Malaysia Melaka

Dr. Deden Witarsyah Telkom University

Dr. Baichuan ZhangIndiana University Indianapolis

Dr. Hendrick National Kaohsiung University of Science and Technology, Taiwan 


\section{Track A Electrical and Electronic Engineering}

EE-1 Dirac Optical Materials for Low-Power All-Optical Plasmonic Devices

Kelvin J.A.Ooi, Qingwei Zhai, C.K.Ong (Xiamen University Malaysia) Yee Sin Ang, L.K.

Ang, Dawn T.H. Tan, (Singapore University of Technology and Design)

EE-2 Low-Power CMOS Variable Gain Amplifier for Modern RF Receivers

5

M.A.S.Bhuiyan, Z.Fan, Y.W.Wei, G.F. Kaim (Xiamen University Malaysia), M.B.I. Reaz

(Universiti Kebangsaan Malaysia), M.T.I. Badal (RMIT University, Australia)

EE-3 SWIPT-Assisted Device-to-Device Communications Underlaying a Cellular System

Hieu V. Nguyen, Hyeon Min Kim, Gil-Mo Kang, Yoan Shin, and Oh-Soon Shin (Soongsil University, Korea)

EE-4 Simulation of Link Failure Handling in Jellyfish Topology on Software Defined Networks Using Floyd-Warshall and Johnson Algorithm

Muhammad Arief Nugroho, Andrian Rakhmatsyah, Regita Anjani (Telkom University, Indonesia)

EE-5 Design of an Indoor Localization System Based on WLAN for Assisting Victim's Evacuation Process

Viska Mutiawani, Cut Thifal Nazila, Kurnia Saputra, Amalia Mabrina MR (Syiah Kuala University Banda Aceh, Indonesia)

EE-6 Three-Phase Direct Matrix Converter With Space Vector Modulation for Induction Motor Drive Era Purwanto, Farid Dwi Murdianto, Dahried Wahyu Herlambang, Gamar Basuki, Mentari Putri Jati (Politeknik Elektronika Negeri Surabaya, Indonesia)

EE-7 Implementation of Single Stage Converter (Z-Source Inverter) For Induction Motor Supply Indra Ferdiansyah, Era Purwanto, Lucky Pradigta S.R, Diah Septi Yanaratri, Rachma Prilian Eviningsih, Tita Aprilia (Politeknik Elektronika Negeri Surabaya, Indonesia)

EE-8 Multi Agent Protocol for Cooperative Rear-end Collision Avoidance System

Noor Cholis Basjaruddin(Politeknik Negeri Bandung), Zakka Izzatur Rahman Noor, Dwi Hendratmo Widyantoro (Institut Teknologi Bandung, Indonesia)

EE-9 Design Of Single Phase Full Bridge Inverter for Uninterruptible Power Supply (UPS) Epyk Sunarno, Indhana Sudiharto, Indra Ferdiansyah, Syechu Dwitya Nugraha, Ony Asrarul Qudsi, Mahbub Gusti Muhammad ( Politeknik Elektronika Negeri Surabaya, Indonesia)

EE-10 Design of Battery Charging System as Supply of Rice Threshers in Tractor

Sutedjo, Indra Ferdiansyah, Ony Asrarul Qudsi, Fandi Setiawan (Politeknik Elektronika Negeri Surabaya, Indonesia)

EE-11 Movement Control of Two Wheels Balancing Robot Using SMC Based on Lyapunov Analysis

Nurul Hasanah, Syadza Atika Rahmah, Wulandari Puspita Sari, Niam Tamami' Alrijadjis, Bambang Sumantri (Politeknik Elektronika Negeri Surabaya, Indonesia) 
EE-12 An Unorthodox Way of Farming Without Intermediaries Through Blockchain

Nabella Shovon Paul, Jubair Islam Joy, Shaila Sarker' Abdullah - Al - Haris Shakib, Sharif Ahmed, Amit Kumar Das (East West University, Bangladesh)

EE-13 Security Concerns of Ridesharing Services in Bangladesh

Shamse Tasnim Cynthia, Moname Majumder, Anika Tabassum, Nazmun Nahar Khanom, Rashedul Amin Tuhin, Amit Kumar Das (East West University, Bangladesh)

EE-14 LACP Experiment Using Multiple Flow Table in Ryu SDN Controller Farid Baskoro, Risanuri Hidayat, Sigit Basuki Wibowo (Universitas Gadjah Mada)

EE-15 Separation of Acoustic Signals on a Compressor Using FastICA Anindita Adikaputri Vinaya ${ }^{1}$, Sefri Yulianto ${ }^{2}$, Qurrotin A'yunina M. Okta Arifianti ${ }^{3}$, Dhany Arifianto ${ }^{4}$, Aulia Siti Aisjah (Universitas Internasional Semen Indonesia Gresik, Indonesia)

DDoS Detection on Network Protocol Using Neural Network with Feature Extract Optimization

Andi Maslan,Sestri Novia Rizki (Universitas Putera Batam Batam Indonesia) Kamaruddin Malik Mohammad, Feresa Binti Mohd Foozy (Universiti Tun Hussein Onn Malaysia)

\section{Track B Artificial Intelligents}

AI-1 Prediction of Semantically Correct Bangla Words Using Stupid Backoff and WordEmbedding Model

Tanni Mittra, Linta Islam, Deepak Chandra Roy (West University Dhaka, Bangladesh)

AI-2 Priority Path for Mutant Repairs on Mutation Testing

Sasa Ani Arnomo (Universitas Putera Batam, Indonesia), Noraini Binti Ibrahim (Universiti Tun Hussein Onn Malaysia)

AI-3 Participatory Heuristic Evaluations of Jeliot Mobile : End-users Evaluating Usability of Their Mlearning Application

Muhammad Mustafa Hassan (University of Eastern Finland, Finland)

AI-4 Comparative Study on Handwriting Recognition by Machine Learning Anandika Sharma, Anupam Sharma (Institute of Engineering and Technology Patiala, India)

AI-5 Optimization of Genetic Algorithms on Backpropagation Neural Network to Predict National Rice Production Levels Aditya Wisnugraha Sugiyarto, Dhoriva Urwatul Wutsqa, Novia Hendiyani, Achmad Ramadhanna'il Rasjava (Yogyakarta State University, Indonesia)

AI-6 Ultra Step Up Converter Using Fuzzy Sugeno on HVDC Application Arman Jaya, Farid Dwi Murdianto, Era Purwanto, Ardiansyah Rachmatdianto (Politeknik Elektronika Negeri Surabaya, Indonesia)

AI-7 Implementation of Maximum Power Point Trackingon Solar Panels using Cuckoo Search Algorithm Method Indra Ferdiansyah, Sutedjo, Ony Asrarul Qudsi, Alvin Noer Ramadhan (Politeknik Elektronika Negeri Surabaya, Indonesia) 
AI-8 Classification of Segmented Milkfish Eyes Using Cosine K-Nearest Neighbor

Eko Prasetyo, R. Dimas Adityo, Rani Purbaningtyas (University of Bhayangkara Surabaya, Indonesia)

AI-9 Bangla Word Prediction and Sentence Completion Using GRU: an Extended Version of RNN on N-Gram Language Model

Omor Faruk Rakib, Shahinur Akter, Md Azim Khan, Amit Kumar Das, Khan Mohammad Habibullah (West University Dhaka, Bangladesh)

AI-10 An Intelligent Approach for English Word Prediction Using Deep Neural Network Omor Faruk Rakib, Shahinur Akter, Md Azim Khan, Amit Kumar Das (West University Dhaka, Bangladesh)

AI-11 Hyper-parameter Determination of CNN Classifier for Head Pose Estimation of Three Dimensional Degraded Face Images

Randy Pangestu Kuswana, Akhmad Faqih, Benyamin Kusumoputro (Universitas Indonesia Depok, Indonesia)

AI-12 Detecting Distributed Denial of Service Attack Using Logistic Regression and SVM Methods

Mohammad Arafat Ullah, Arthy Anjum Jamal, Rashedul Amin Tuhin, Shamim Akhter (West University Dhaka, Bangladesh)

AI-13 Robustness Analysis of PI Controller to Optimizing The Output Power for Energy Management in DC Microgrid System Indhana Sudiharto, Epyk Sunarno, Farid Dwi Murdianto, Eni Wulandari (Politeknik Elektronika Negeri Surabaya, Indonesia)

AI-14 Designing Mamdani Fuzzy Inference Systems for Decision Support Systems Humaira, Rasyidah, Indri Rahmayuni ( Politeknik Negeri Padang, Indonesia)

AI-15 Measurement of Stain Area in Metal Surface with Particle Analysis Riandini, Shahnan Kamil Dewantoro, Reza Istoni (Politeknik Negeri Jakarta, Indonesia)

IOS Mobile APP for Tuberculosis Detection Based on Chest X-Ray Image

Hendrick, Wang Zhi-Hao, Chen Hsien-I, Chang Pei-Lun, Jong Gwo-Jia (University of Science and Technology Kaohsiung, Taiwan)

\section{Track C Information Systems}

IS-1 A Variable Sampling Interval Run Sum Chart for The Mean with Auxiliary Information

Faijun Nahar Nim, Michael Boon Chong Khoo ( Universiti Sains Malaysia), Sajal Saha (University of Business Agriculture and Technology, Dhaka Bangladesh)

IS-2 Analysis of The Effect of Quality Mulawarman University Language Center Websites on User Satisfaction Using The Webqual 4.0 Method Muhammad Bambang Firdaus, Novianti Puspitasari, Edy Budiman, Joan Angelina Widians, Nur Bayti (Mulawarman University Samarinda, Indonesia) 
IS-3 Master Data Management Maturity Assessment: Case Study of XYZ Company Handayani, Nabila Clydea Harahap ( Universitas Indonesia, Indonesia)

IS-4 The Evaluation of Finance Module Implementation of Enterprise Resource Planning (ERP) for Employee Performance

Dayane Kamila Hafifah, Deden Witarsyah, Muhardi Saputra, Anik Hanifatul Azizah, Marhaeni Eka Saputri ( Telkom University)

IS-5 Content-based Image Retrieval System for Locating Building in Syiah Kuala University Using Android Platform

Nazaruddin, Kurnia Saputra, Amalia Mabrina Masbar Rus, Dedek Fitri

(Universitas Syiah Kuala Banda Aceh, Indonesia)

IS-6 Integrating Nagari Information in West Sumatera with Laravel Framework Hidra Amnur, Rasyidah, Yance Sonatha (Politeknik Negeri Padang)

IS-7 The State of the Art in e-Tendering Technology and Implementation Syifa Nurgaida Yutia, Budi Rahardjo ( Institut Teknologi Bandung, Indonesia)

Yohanes Priadi Wibisono, Clara Hetty Primasari, Alwi Kesuma (Universitas Atma Jaya Yogyakarta, Indonesia)

IS-9 Design of Electronic Medical Record Security Policy in Hospital Management Information System (SIMRS) in XYZ Hospital

Hana Avianto, Dion Ogi ( Sekolah Tinggi Sandi Negara Bogor, Indonesia )

IS-10 Sales Data Monitoring Systems Telkom Indonesia Witel Samarinda Field Business Goverment and Enterprise

Andi Tejawati, Muhammad Bambang Firdaus, Sugesty Pramana Aditya, Edy Budiman, Masna Wati, Medi Taruk (Mulawarman University, Indonesia)

IS-11 Impact of Social Media on Socialization of University Students (A study on East West University's Undergraduate Students)

Maliha Hassan, Anik Saha, Nujat Saba, Rashedul Amin Tuhin, Amit Kumar Das (East West University, Dhaka, Bangladesh)

IS-12 Software Piracy : Factors and Profiling

Afsana Hossain, Jahidul Hoque, Amit Kumar Das, Nishat Tasnim Mim, Jahidul Hoque, Rashedul Amin Tuhin (East West University, Dhaka, Bangladesh)

IS-13 Digital Governance for Pension Withdrawal System in Bangladesh

Shamima Sultana, Mohammad Hemayet Ullah, Sumiya Akter Nisher, Md. Shahad Iqbal, Md. Rashedul Amin Tuhin, Amit Kumar Das (East West University, Dhaka, Bangladesh

IS-14 Hotel Room Price Determination Based on Dynamic Pricing Model Using Nonlinear Programming Method To Maximize Revenue

Muhammad Fadly, Ari Yanuar Ridwan, Mohammad Deni Akbar ( Telkom University, Indonesia) 
IS-15 A Behavioral Model of Music Piracy in Bangladesh : Factors Influencing Music Piracy

Syed Sahariar Hassan, Fatema Nihar, Maimuna Rahman, Md Washim Razu, Rashedul Amin Tuhin, Amit Kumar Das (East West University, Dhaka, Bangladesh)

\section{Track D Computer Engineering}

\section{CE-1 Side Sensitive Group Runs $\boldsymbol{t}$ Control Chart}

Sajal Saha (University of Business Agriculture and Technology, Dhaka Bangladesh)

Faijun Nahar Nim, Michael Boon Chong Khoo ( Universiti Sains Malaysia)

CE-2 Performance Evaluation of MongoDB, Cassandra, and HBase for Heterogenous IoT Data Storage

Eko Sakti Pramukantoro, Dany Primanita Kartikasari, Reza Andria Siregar(Brawijaya University, Indonesia)

CE-3 Implementation of Hybrid Password Authentication Scheme Based on Shape-Text on Raspberry Pi as a Client-Server-Based Access Control System to Overcome Shoulder Surfing Attack

Alfian Andre Anto, Dian Ogi (Sekolah Tinggi Sandi Negara, Indonesia)

CE-4 An Analysis on Python Programming Language Demand and its Recent Trend in Bangladesh

Aaquib J, Monika Z, Tasnova N (North South University, Dhaka Bangladesh)

CE-5 Crowdsourced Transport Management System for Smartphone Users Md.Sohel Rana, Md. Jakir Hosen, Abdullah Al Noman, Linta Islam, Tanni Mittra (East West University, Dhaka, Bangladesh)

CE-6 Image Fusion-based Multi-frequency Microwave Tomography Sebastian Siburian, Sastra Kusuma Wijaya, Prawito Prajitno (Universitas Indonesia)

CE-7 A Simulation of Enhanced Oil Recovery of Surfactant Flooding Using Sodium Lignosulfonate by CMG-STARS

Sukmana, Anggara, Azis, Cahyono (Universitas Gadjah Mada, Indonesia), Putra

(Universitas Islam Riau, Indonesia)

CE-8 Performance Analysis of Simple Capacitive Cylinder Sensor for Measuring Soil Moisture Content

Radi, Bambang Purwantana, , Anditya Sridamar Pratyasta, Bayu Kuncoro,

Nadia Umi Hanifah,( Universitas Gadjah Mada) Muhammad Rivai (Institut Teknologi Sepuluh Nopember)

CE-9 Potency of Image Color \& Textural Feature for Granular Size Estimation of Ground Coffee

Radi, Bambang Purwantana, , Anditya Sridamar Pratyasta, Bayu Kuncoro, Nadia Umi Hanifah,( Universitas Gadjah Mada) Muhammad Rivai (Institut Teknologi Sepuluh Nopember) 


\section{e-Vent: Support System for Event Registration}

\author{
$1^{\text {st }}$ Yohanes Priadi Wibisono \\ Department of Information System \\ Universitas Atma Jaya Yogyakarta \\ Yogyakarta, Indonesia 55281 \\ priadi.wibisono@uajy.ac.id
}

\author{
$2^{\text {nd }}$ Clara Hetty Primasari \\ Department of Information System, \\ Universitas Atma Jaya Yogyakarta, \\ Yogyakarta, Indonesia, 55281 \\ clara.hetty@uajy.ac.id
}

\author{
$3^{\text {rd }}$ Alwi Kesuma \\ Department of Information System, \\ Universitas Atma Jaya Yogyakarta \\ Yogyakarta, Indonesia, 55281 \\ alwi.kesuma.ak@gmail.com
}

\begin{abstract}
Registration, ticketing, and valid certificates are a series of work that must be done by event organizer. The registration, ticketing, and certificate issuance stages are often carried out using conventional or manual methods using stationery, print, and paper media. The conventional method is often an obstacle that causes the program to run less smoothly. This problem can be overcome by applying e-registration technology and QR Code as a substitute for tickets and ecertificates. Cellular technology such as smartphone can be the right solution for event organizers to overcome these obstacles. The application of an event registration system (e-Vent) that combines e-registration technology and QR Code as validation of registration and certificates is an effective and easy solution in implementing the stages of procuring an event. With ERegistration, data on participants who have registered will be stored in the database and will be displayed using the QR Code as the entry ticket sent to the participant's email. With this, QR Code readers can access data quickly to validate event participant data. The process of filling out the registration form can be done anywhere and anytime and the registration verification process can be done more quickly and accurately through this e-Vent system. The e-Vent system is designed using the FAST method and uses CodeIgniter as a development framework for web admins and Android Studio as a tool for developing QR Code reader validator applications.
\end{abstract}

Keywords - registration; event; QR Code; ticketing; certificates; validation

\section{INTRODUCTION}

The development of increasingly advanced and rapid information technology has now spread in almost all fields such as education, event organizer, business, health, and government. Information technology has enhanced the ability to exchange knowledge, and accelerate the flow of information and communication [1]. in addition, its use can also have a positive impact on business productivity and performance [2]. This technology plays a very important role to ensure the organization runs more effectively and efficiently, one of which is when an event is held. One series of activities in organizing an event is the registration of participants. Registration is done to collect prospective participant data regarding the event to be held. An organization that organizes an event or event requires a registration process for participants to take part in the event. Therefore, a registration process that is fast, precise, and easy is needed so that the event is held as expected.
Registration is one of the important aspects that are needed by the organization when conducting an activity or event such as a seminar, show, conference, etc. Registration will always be required for prospective participants to participate in an activity by entering their data. Meanwhile for the organizers, registration is needed to monitor participants' personal data and the number of participants who attend certain events. With this registration process, event organizers can also confirm to participants who have filled in their personal data regarding the certainty of attendance.

The registration process that is done manually requires more costs for the purchase of stationery and registration paper so that it tends to be inefficient and there may be problems when registering. The use of paper is also very risky for possibilities such as being torn, burned, destroyed by water, or may be lost due to misplacement. Meanwhile, the process of validating participants with signatures when reregistration using paper media can take a long time especially if the number of participants reaches hundreds. The need for places for registration and registration staff can also incur additional costs. With the adoption of e-registration, it is expected that event organizers will benefit in terms of ease of error correction, more accurate and consistent data recording, easy data retrieval, storage, access, confirmation, avoiding unauthorized data access, reducing paper usage, increasing portability / mobility in data recording and backup, and shorter processing time. From the user side, it is expected that users will be more facilitated in the registration process [3].

The current trend in the use of information technology, especially smartphones, has touched almost all people. This telecommunications technology is developing very rapidly following the needs of the community for practical and flexible media to support their daily activities. With the widespread use of smartphones, this can be an opportunity that the smartphone can be used for the registration system at an event. One of the features of a smartphone that is interesting to use is the camera features. The camera feature that has been installed in almost all smartphones can be used for the application of a validation system by using it as a QR (Quick Response) Code reader. QR Code is one of the popular technologies because it is cheap, easy to produce, and easy to use when compared to other technologies [4].

The transformation from the manual registration process that was changed to mobile technology through the eRegistration system and validation using the QR Code will 
make it more effective and efficient. This transformation can be the right solution by developing an e-Vent mobile application that utilizes website technology as e-Registration and QR Code simultaneously. e-Vent is a registration system that uses QR Code technology as proof of validation of event registration and website technology as a place of registration.

This e-Vent system will be used as a registration form that can store participant data so it is more efficient because it does not require paper and saves on site costs because registration is done through the website. Invitations or event entry tickets as proof of registration will be in the form of a QR Code image that will be sent via e-mail after participants register. For participant validation, the organizer only needs to scan the participants' QR Code using the QR Code Scanner through the smartphone camera.

The advantage of implementing e-Vent for participants is that participants have the flexibility to register. Participants can register anywhere and anytime as long as they have a smartphone. The convenience and time savings in reregistering are also obtained by participants because proof of registration in the form of a QR Code can be shown via a smartphone. Therefore, participants do not need to wait long to re-register because they only need to display the QR Code into the scanner camera or QR Code Scanner so that participants can directly enter the event.

For the committee, the advantage of implementing e-Vent is saving in terms of costs, time and human resources needed. The committee will save costs from using paper for registration and credit fees for attendance confirmation needs because it is done through the system. The committee also does not need a location to open registration stands and registration staff so that costs can be reduced. Deletion of invitations, tickets, or ID cards can be done because they have used the QR Code sent via e-mail to each participant. The participant's certificate will be in the form of a softcopy that is sent to the participant's e-mail, reducing the cost for printing the certificate. The re-registration process will take less time, thereby reducing the buildup of participants at the registration desk.

Based on the description above, it can be concluded that the event registration system developed aims to help organizations manage registration of participants more easily, quickly, precisely, and efficiently than manual methods. Losses and problems that arise when using manual methods can be avoided by using this registration system in terms of cost, time, and resource as well as the security of participant data which is certainly more secure.

\section{LITERATURE REVIEW}

Event is an activity that collects a set of target people in a certain space and time, then a meeting takes place whose message is communicated to those people. The event describes different activities for different purposes [5].

Registration is a process, method, act of registering, recording names, addresses, etc. on the list. Registration is the process of recording the identity of the registrant into a storage media used in the registration process.
Adoption can be defined as the decision to make full use of innovation as the best available action. Whereas adoption of innovation is a process in which an individual switches from first knowledge about innovation to a decision to adopt or reject and to confirm this decision [6]. E-registration is also known as electronic registration or web-based registration or even online registration. This online registration system replaces manual processes such as registering via telephone, mail, or directly at the event using paper forms [7]. In addition, depending on the underlying model, documents can be digitally signed [8].

Event Organizer are parties responsible for managing events such as festivals, social events such as gatherings, meetings, conferences, etc [9].

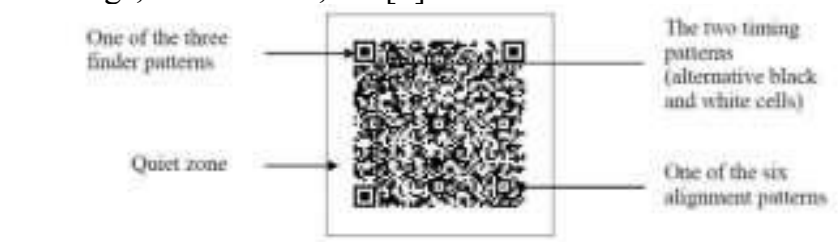

Fig. 1. Example of QR Code [10]

The QR Code (Quick Response Code) is a trademark for machine-readable optical labels that contain information about the items attached [11]. The code in the QR Code is a twodimensional barcode. The QR Code was developed by Denso Wave, a Denso Corporation division which was a Japanese company and was published in 1994. QR codes are read with cameras or QR scanners. Figure 1 shows an example of a QR Code.

\section{Methodology}

2 .

The stages of research used in this study shown in Figure

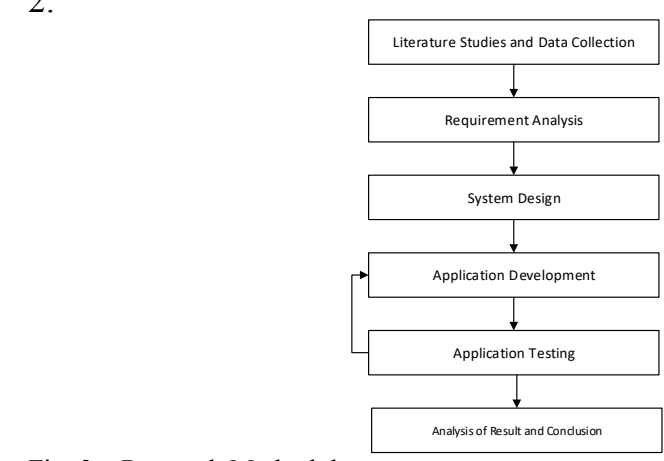

Fig. 2. Research Methodology

\section{1) Literature Studies and Data Collection}

At this stage a study of the Framework Development will be used and data collection. There are two types of data used in this study, namely primary data and secondary data.

a. Primary data

Primary data is obtained from observation, interviews, or questionnaires [12]. In this study the primary data is data relating to the need for registration in an event. To obtain these data, researchers will conduct interviews with event organizers or event organizers and committees on campus.

b. Secondary Data

Secondary data is data that already exists, or can be said as data that has been collected and analyzed by other parties. 
Secondary data can be obtained from various sources such as publications, books, magazines, newspapers, reports, recordings and reports on general statistics, etc [12]. To obtain these data the researcher took several books, brochures, websites, and examples of previous research related to this research, namely regarding the flow of registration of participants in an event.

The data collection method used in this study is the Interview method. Interviews are appropriate for cases or questions that require investigation to obtain sufficient information. There are three types of interviews, including: structured, unstructured and semi-structured interviews [13]. The researcher will interview several event organizers and Student Association committees to obtain certain data, especially if the data obtained through the documentation method is unclear.

Population is the term collection to describe the total quantity of an object or case under study. Population can consist of several types of objects, organizations, people, or events [13]. The population used is the party that acts as an event organizer and student committee.

2) Requirement Analysis

In the requirement analysis phase there are primary and secondary data analysis activities, determining system indicators, system indicator analysis, extracting system requirements that are in accordance with the indicators' achievements, and documenting system requirements.

3) System Design

At this stage there are design activities, requirements, process flow, database, applications, and interfaces.

4) Application Development

At this stage an application development is carried out consisting of coding, interface creation, and system installation. The system development method used in this research was FAST method with prototyping as an approach method. FAST is an agile methodology that is flexible enough to support a variety of projects and system development strategies [14]. The letters in FAST stands for "Framework for the Application of the System Thinking". FAST can be said as a best practice from previous methodologies to support the development system and support the system life cycle. FAST method with a prototyping approach chosen based on several considerations:

1. The Prototyping approach involves a lot of users, so it can increase system visibility and get more support from users and management.

2. The Prototyping approach is faster, cheaper, and does not require a large development team. These factors lead to the prototyping approach in accordance with a medium-sized system, such as the system to be developed.

3. Prototyping approach can make it easier for users to know their desires. In prototyping, the system consists of several cycles, in which each cycle the team produces a prototype. The results of this evaluation will be analyzed again by the development team and then produce a new prototype. Thus this cycle will continue until the system is obtained in accordance with the wishes of the user. Prototyping cycle shown in Figure 3.

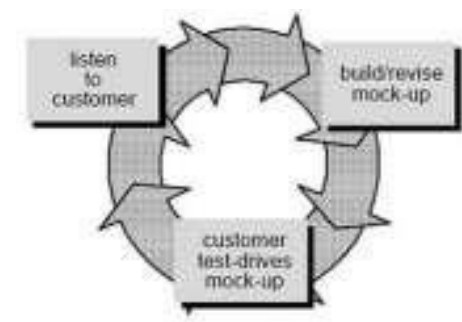

Fig. 3. Prototyping Cycle [15]

\section{5) Application Testing}

After implementation, a system evaluation will be held. System evaluation will be carried out at first, second and third year. From this evaluation, results will be obtained which will be used to improve the system every year.

6) Analysis of Results and Conclusions

At this stage, the results of the analysis are carried out and conclusions are drawn.

\section{RESULT AND DISCUSSION}

Based on the results of observations and interviews with student committees and several event organizers, there were several problems from the participant registration flow to the granting of participant certificates. Figure 4 shows the registration of participants in an event until the acceptance of event certificates by participants using conventional methods.

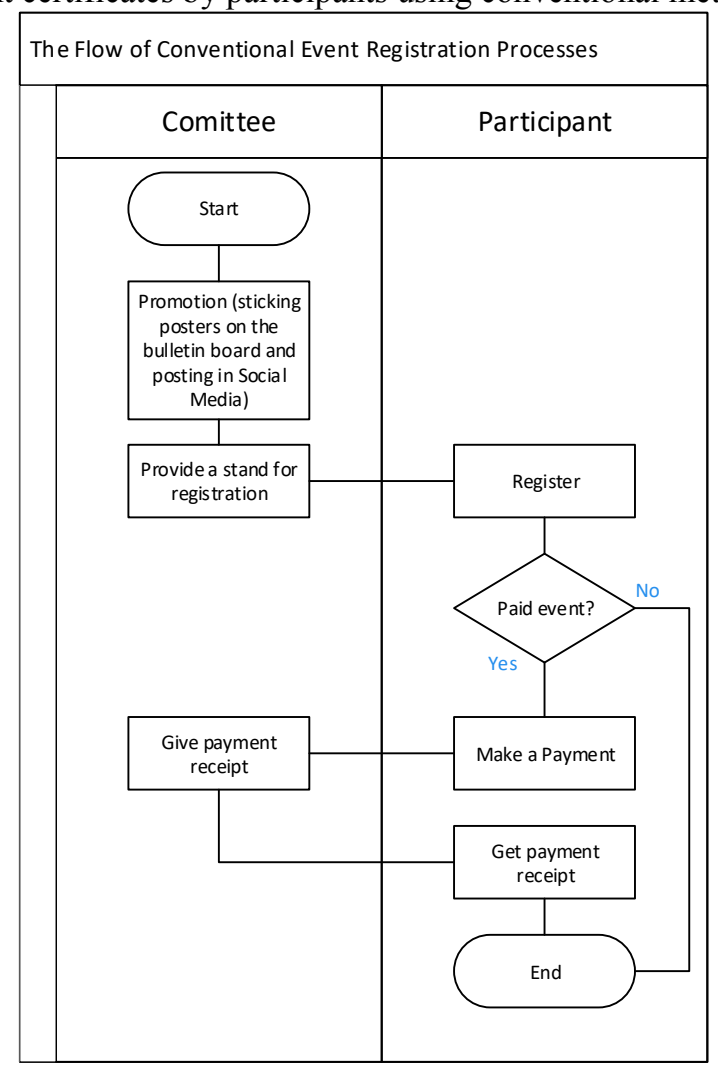

Fig. 4. Conventional Event Registration Flowchart

Figure 5 shows process flow from participant registration to giving certificates to participants. 


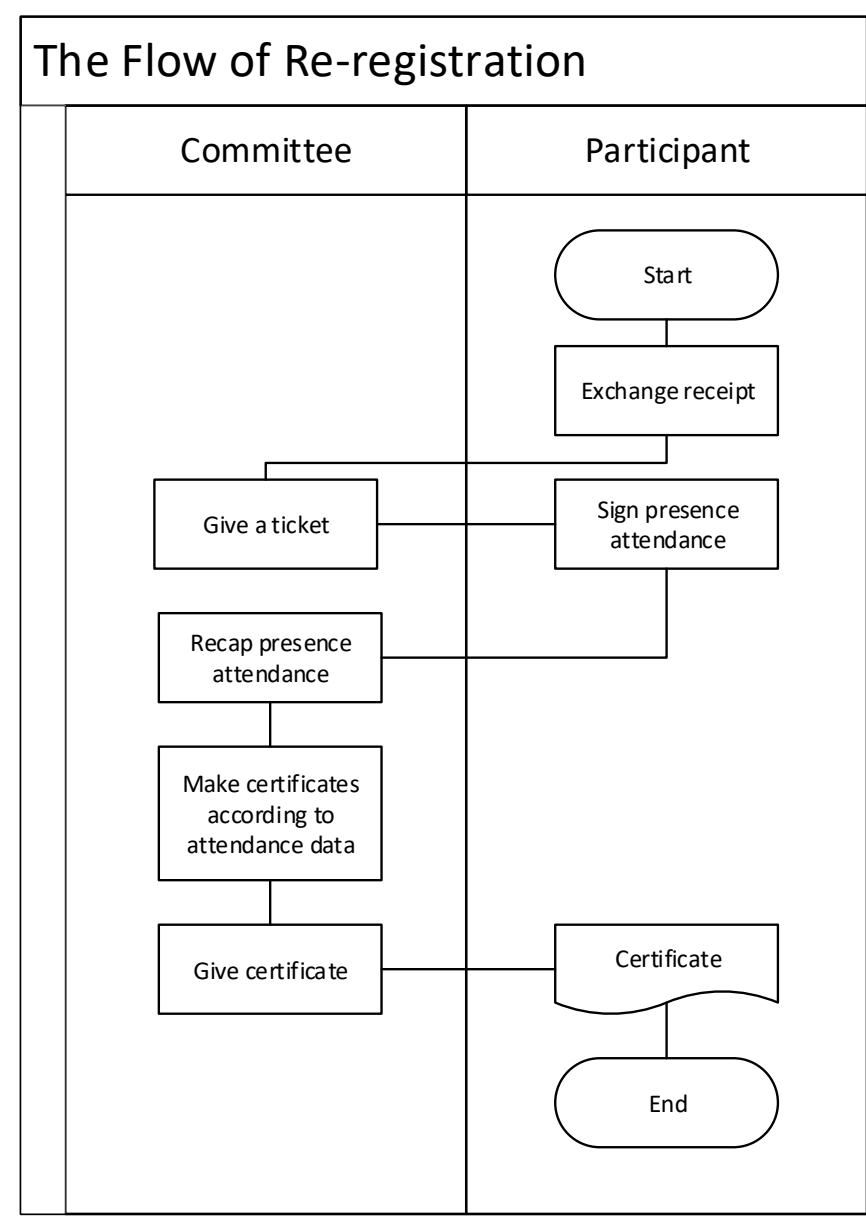

Fig. 5. Conventional Event Re-registration Flowchart

However, conventional registration method has several weaknesses and problems. Analysis of problems that arise from convention method and the solution offered such as:

1. Problem: During registration, Event organizers tend to still use paper as a media for participant registration so that potential participants must come or even queue to register for the event. In addition, the use of paper has the potential to be damaged or lost.

Solution offered: The application of a website-based online event registration system so that prospective participants can register wherever and whenever they are without having to queue. Prospective participants who have registered online through the web will receive e-tickets and $\mathrm{QR}$ codes via email. The event committee also does not need to archive registration paper or form again because all participant registration data has been stored in the system database.

2. Problem: During Re-registration, Event organizers tend to still use paper as a participant registration media, causing participants to come or even queue to enter the location of the event. Again, the use of paper has the potential to be damaged or lost.

Solution Offered: The application of the online event registration system also provides a QRCode Reader feature for event organizers to replace conventional verification methods such as participant presence form using paper. QR codes obtained by participants after registering will be shown to the event committee during the registration process to verify their attendance. With the transition of the registration process from the paper media presence method to attendance verification by scanning the QRcode participant using the QR Code Reader, it is expected that the participants' queuing time and the user of presence attendance paper can be reduced.

3. Problem: For ticketing, events held still tend to use physical tickets which require the committee to issue ticket printing costs. Physical tickets purchased by participants after registration must be taken when attending the event as proof of registration. Such physical tickets have the potential to be lost or damaged so that they can harm participants in terms of material.

Solution offered: The application of an online event registration system provides an e-ticket in which there is also a participant's QR code to replace the physical ticket. The e-ticket was sent to the participant's e-mail according to the e-mail registered. When participants attend the location during the event, Participants only need to show the e-ticket to the event committee. The $\mathrm{QR}$ code listed in the e-ticket will be scanned using the mobile app to verify participants' attendance. By utilizing QRCode and its Reader tools, it is expected to reduce physical ticket loss or damage.

4. Problem: In terms of certificate given, current events tend to provide physical certificates for participants as proof of participation. These physical certificates require the committee to spend printing cost. In addition to printing costs, the committee needs to distribute certificates to all attendees after the event ends. This creates a process that is not efficient in terms of time and cost. The committee must look for participant certificates when distributing them, at the same time participants must provide time to queue again after the event ends in order to get a certificate.

Solution Offered: The application of an online event registration system provides participant e-certificate features. When the participant's QRcode has been scanned by the committee using a QR Code Reader and its presence has been verified, the participant can download the e-certificate from the website by entering the full name that has been registered and the registrant's ID listed on the e-ticket. With the presence of the e-certificate feature, the committee does not need to share certificates one by one with participants and does not need to pay the cost of printing certificates and participants do not need to queue again to the committee table to obtain certificates.

After analysing problems and offering solution, conventional registration process can be simplified using the help of event 
registration system. The flow of the event registration process that uses QRCode on e-Vent shown in Figure 6.

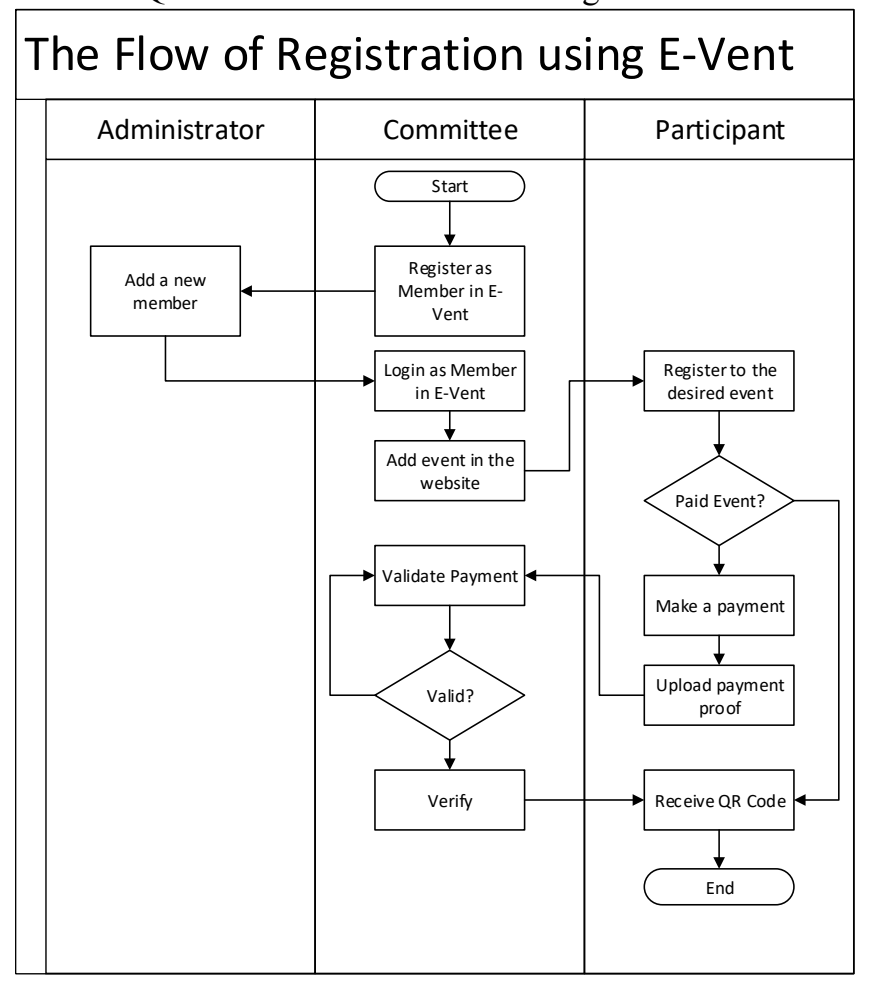

Fig. 6. Event Re-registration using E-Vent Flowchart

Network Architecture of E-vent Registration System shown in Figure 7.

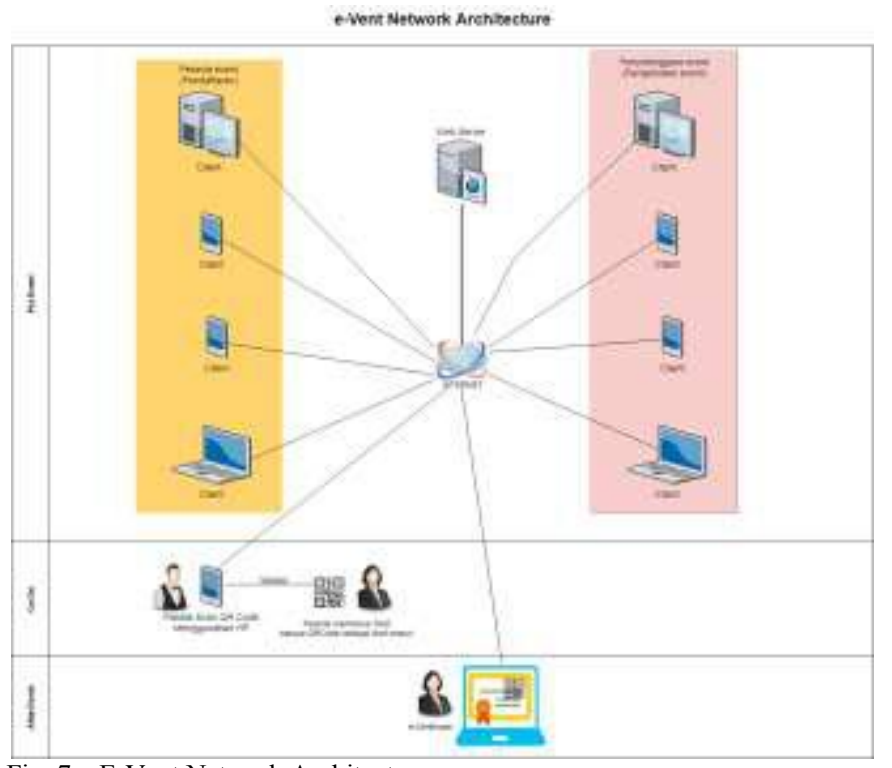

Fig. 7. E-Vent Network Architecture

Based on the solutions mentioned before and e-Vent architecture, the researcher developed a system for managing registration, ticketing, QR code reader \& validation and ecertificate using framework codeIgniter as a backend, ciqrcode library as a QR code generator, MySql for storing databases, and Android Studio for the development of a QR code reader and data validation.
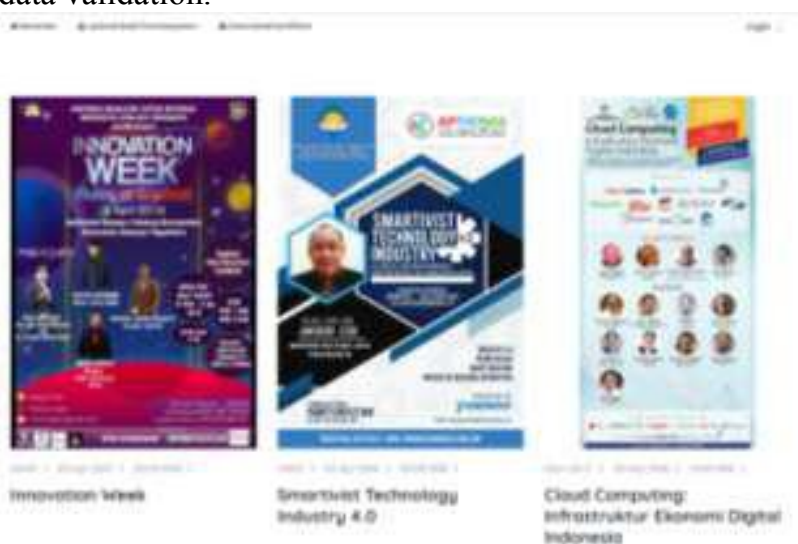

Fig. 8. E-Vent Landing Page

At the landing page shown in Figure 8, the systems will be displayed a list of events held by event organizers who have been registered as members. Prospective participants can choose the event to be attended and see detailed information from the event. In this view there are some general information on the event such as time, place, ticket price, participant quota. Furthermore, prospective participants can immediately register themselves through eventkampus.info prospective participants choose the event they want. The registration form shown in Figure 9.

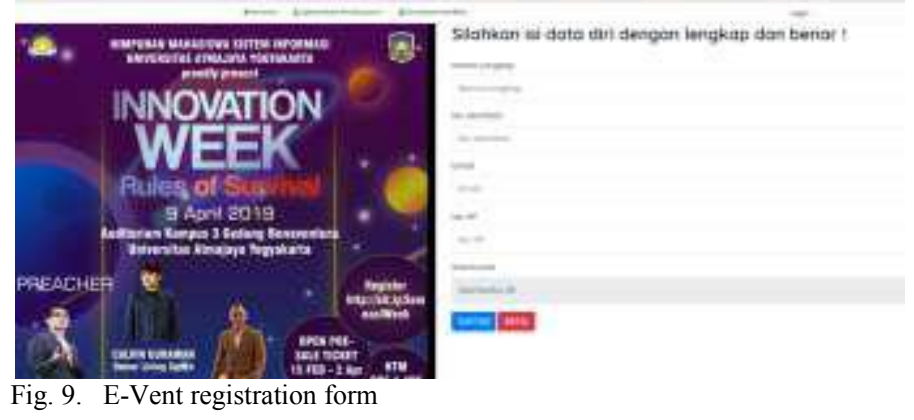

If the event is a paid event, the participants have to make a payment first and then upload proof of payment in the Upload Payment Proof Form shown in Figure 10.

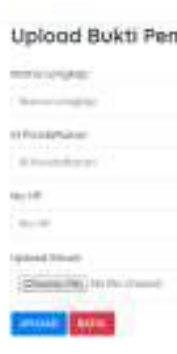

Fig. 10. E-Vent registration form

After the Participant has uploaded proof of payment, proof of payment will be verified by the committee. If verified, the ticket in the form of a QR Code will be sent directly by e-mail to participants. On the ticket there are several information 
such as date, time and place, and there is a QR Code that contains participant data. E-ticket shown in Figure 11.

\begin{tabular}{|c|c|}
\hline BUKTI REGISTRASI & 몾몬 \\
\hline $\begin{array}{l}\text { Dear. Romualdus } \\
\text { Sumbogo }\end{array}$ & $\begin{array}{l}\text { Id } \\
\text { Pendattoran: } \\
\text { F19000014 }\end{array}$ \\
\hline $\begin{array}{l}\text { Salam Sejahtera, } \\
\text { Terimakasih Anda telah } \\
\text { mendaftar acara } \\
\text { Innovation Week yang } \\
\text { akan dilaksanakan pada: }\end{array}$ & \\
\hline $\begin{array}{l}\text { Tanggal:09 Apr } 19 \\
\text { Waktu 03:00 WIB }\end{array}$ & \\
\hline Tempat: Auditorium & \\
\hline $\begin{array}{l}\text { Untuk kelancaran acara } \\
\text { ini dimohon untuk } \\
\text { menyimpan Bukti } \\
\text { Registrasi ini dengan } \\
\text { Baik. }\end{array}$ & \\
\hline $\begin{array}{l}\text { Salam hormat, } \\
\text { Panitia }\end{array}$ & \\
\hline
\end{tabular}

Fig. 11. E-Vent E-ticket

During the day of the event, participants simply show the QR Code shown in E-ticket to be scanned by the committee using mobile apps that function as participant identity validators. The scanning process will change the status of participants in the database from 'not present' to 'attend'. If the event participant's status has been validated, then the event participant will be able to download e-certificate through the "Download Certificate" menu shown in Figure 12.

\section{Download Sertifikat !}

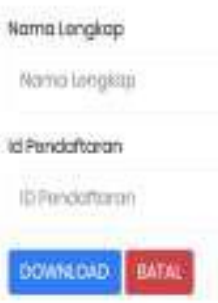

Fig. 12. Download Certificate Menu

\section{CONCLUSION}

Events held in Indonesia tend to apply processes that are still using conventional methods. The conventional method causes some processes to be inefficient in terms of time and cost. Processes that run inefficiently such as the process of registering participants, re-registering participants, ticketing, and giving participant certificates. With the presence of EVent, it is expected to increase efficiency in these processes, especially in the registration process such as the presence of online registration features, e-tickets, QRCodes, and ecertificates. E-Vent offers convenience in managing participant and event data, participant registration, administration and validation, and certificate distribution because it can be done anywhere and anytime.

\section{ACKNOWLEDGMENT}

This research was supported by Lembaga Penelitian dan Pengabdian Masyarakat (LPPM) Universitas Atma Jaya Yogyakarta.

\section{REFERENCES}

[1] S. Mitić, M. Nikolić, J. Jankov, J. Vukonjanski, and E. Terek, "The impact of information technologies on communication satisfaction and organizational learning in companies in Serbia," Comput. Human Behav., vol. 76, pp. 87-101, 2017.

[2] N. I. Jabbouri, R. Siron, I. Zahari, and M. Khalid, "Impact of Information Technology Infrastructure on Innovation Performance: An Empirical Study on private Universities In Iraq," in Procedia Economics and Finance, 2015.

[3] T. Johnson, M. Edinborough, Joshua Binder, A. Bryant, B. Dennis, and E. Al., "Dynamic Registration Forms," in Proceedings of the International Conference on Software Engineering Research and Practice (SERP), 2013.

[4] M. Pérez-Sanagustín, D. Parra, R. Verdugo, G. García-Galleguillos, and M. Nussbaum, "Using QR codes to increase user engagement in museum-like spaces," Comput. Human Behav., 2016.

[5] H. Kose, M. Argan, and M. Argan, "Special Event Management and Event Marketing: A case study of TKBL all star 2011 in Turkey," J. Manag. Mark. Res., 2011.

[6] C. Assumptions and E. M. Rogers, "Diffusion of Innovations Theory," New York Free Press, 2003.

[7] P. Chaka, "An Implimentation Of An Online Based Registration System In Tertiary Institutions In Zimbabwe," Int. J. Eng. Res. Technol., vol. 2, no. 10, 2013.

[8] J. O'Sullivan, "eRegistration and eConveyancing in Ireland - the story so far," in Registering the World Conference Dublin, 2007.

[9] A. Saleem, D. A. Bhat, and O. F. Khan, "Review Paper on an Event Management System," Int. J. Comput. Sci. Mob. Comput., vol. 6, no. 7, 2017.

[10] C. Law and S. So, "QR Codes in Education," J. Educ. Technol.Dev. Exch., 2010.

[11] E. Ozkaya, H. E. Ozkaya, J. Roxas, F. Bryant, and D. Whitson, "Factors affecting consumer usage of QR codes," J. Direct, Data Digit. Mark. Pract., 2015.

[12] C. Kothari, Research Methodology: Methods and Techniques. 2004.

[13] N. Walliman, Research Methods The Basics. New York: Taylor \& Francis, 2011.

[14] J. L. Whitten and Lonnie D. Bentley, Systems Analysis and Design Methods. 2007.

[15] R. S. Pressman, Software Engineering A Practitioner's Approach 7th Ed - Roger S. Pressman. 2009. 


\section{icaiti \\ by Clara Hetty}

Submission date: 09-May-2020 12:53PM (UTC+0700)

Submission ID: 1320154308

File name: ICAITI_YP_CHP.pdf (584.44K)

Word count: 3941

Character count: 21899 


\section{e-Vent: Support System for Event Registration}

\author{
$1^{\text {st }}$ Yohanes Priadi Wibisono \\ Department of Information System \\ Universitas Atma Jaya Yogyakarta \\ Yogyakarta, Indonesia 55281 \\ priadi.wibisono@uajy.ac.id
}

\author{
$2^{\text {nd }}$ Clara Hetty Primasari \\ Department of Information System, \\ Universitas Atma Jaya Yogyakarta, \\ Yogyakarta, Indonesia, 55281 \\ clara.hetty@uajy.ac.id
}

\author{
$3^{\text {rd }}$ Alwi Kesuma \\ Department of Information System, \\ Universitas Atma Jaya Yogyakarta, \\ Yogyakarta, Indonesia, 55281 \\ alwi.kesuma.ak@gmail.com
}

Abstract - Registration, ticketing, and valid certificates are a series of work that must be done by event organizer. The registration, ticketing, and certificate issuance stages are often carried out using conventional or manual methods using stationery, print, and paper media. The conventional method is often an obstacle that causes the program to run less smoothly. This problem can be overcome by applying e-registration technology and QR Code as a substitute for tickets and ecertificates. Cellular technology such as smartphone can be the right solution for event organizers to overcome these obstacles. The application of an event registration system (e-Vent) that combines e-registration technology and QR Code as validation of registration and certificates is an effective and easy solution in implementing the stages of procuring an event. With ERegistration, data on participants who have registered will be stored in the database and will be displayed using the QR Code as the entry ticket sent to the participant's email. With this, QR Code readers can access data quickly to validate event participant data. The process of filling out the registration form can be done anywhere and anytime and the registration verification process can be done more quickly and accurately through this e-Vent system. The e-Vent system is designed using the FAST method and uses CodeIgniter as a development framework for web admins and Android Studio as a tool for developing QR Code reader validator applications.

Keywords- registration; event; $Q R$ Code; ticketing; certificates; validation

\section{INTRODUCTION}

The development of increasingly advanced and rapid information technology has now spread in almost all fields such as education, event organizer, business, health, and government. Information technology has enhanced the ability to exchange knowledge, and accelerate the flow of information and communication [1]. in addition, its use can also have a positive impact on business productivity and performance [2]. This technology plays a very important role to ensure the organization runs more effectively and efficiently, one of which is when an event is held. One series of activities in organizing an event is the registration of participants. Registration is done to collect prospective participant data regarding the event to be held. An organization that organizes an event or event requires a registration process for participants to take part in the event. Therefore, a registration process that is fast, precise, and easy is needed so that the event is held as expected.
Registration is one of the important aspects that are needed by the organization when conducting an activity or event such as a seminar, show, conference, etc. Registration will always be required for prospective participants to participate in an activity by entering their data. Meanwhile for the organizers, registration is needed to monitor participants' personal data and the number of participants who attend certain events. With this registration process, event organizers can also confirm to participants who have filled in their personal data regarding the certainty of attendance.

The registration process that is done manually requires more costs for the purchase of stationery and registration paper so that it tends to be inefficient and there may be problems when registering. The use of paper is also very risky for possibilities such as being torn, burned, destroyed by water, or may be lost due to misplacement. Meanwhile, the process of validating participants with signatures when reregistration using paper media can take a long time especially if the number of participants reaches hundreds. The need for places for registration and registration staff can also incur additional costs. With the adoption of e-registration, it is expected that event organizers will benefit in terms of ease of error correction, more accurate and consistent data recording, easy data retrieval, storage, access, confirmation, avoiding unauthorized data access, reducing paper usage, increasing portability / mobility in data recording and backup, and shorter processing time. From the user side, it is expected that users will be more facilitated in the registration process [3]

The current trend in the use of information technology, especially smartphones, has touched almost all people. This telecommunications technology is developing very rapidly following the needs of the community for practical and flexible media to support their daily activities. With the widespread use of smartphones, this can be an opportunity that the smartphone can be used for the registration system at an event. One of the features of a smartphone that is interesting to use is the camera features. The camera feature that has been installed in almost all smartphones can be used for the application of a validation system by using it as a QR (Quick Response) Code reader. QR Code is one of the popular technologies because it is cheap, easy to produce, and easy to use when compared to other technologies [4].

The transformation from the manual registration process that was changed to mobile technology through the eRegistration system and validation using the QR Code will 
make it more effective and efficient. This transformation can be the right solution by developing an e-Vent mobile application that utilizes website technology as e-Registration and QR Code simultaneously. e-Vent is a registration system that uses QR Code technology as proof of validation of event registration and website technology as a place of registration.

This e-Vent system will be used as a registration form that can store participant data so it is more efficient because it does not require paper and saves on site costs because registration is done through the website. Invitations or event entry tickets as proof of registration will be in the form of a QR Code image that will be sent via e-mail after participants register. For participant validation, the organizer only needs to scan the participants' QR Code using the QR Code Scanner through the smartphone camera.

The advantage of implementing e-Vent for participants is that participants have the flexibility to register. Participants can register anywhere and anytime as long as they have a smartphone. The convenience and time savings in reregistering are also obtained by participants because proof of registration in the form of a QR Code can be shown via a smartphone. Therefore, participants do not need to wait long to re-register because they only need to display the QR Code into the scanner camera or QR Code Scanner so that participants can directly enter the event.

For the committee, the advantage of implementing e-Vent is saving in terms of costs, time and human resources needed. The committee will save costs from using paper for registration and credit fees for attendance confirmation needs because it is done through the system. The committee also does not need a location to open registration stands and registration staff so that costs can be reduced. Deletion of invitations, tickets, or ID cards can be done because they have used the QR Code sent via e-mail to each participant. The participant's certificate will be in the form of a softcopy that is sent to the participant's e-mail, reducing the cost for printing the certificate. The re-registration process will take less time, thereby reducing the buildup of participants at the registration desk.

Based on the description above, it can be concluded that the event registration system developed aims to help organizations manage registration of participants more easily, quickly, precisely, and efficiently than manual methods. Losses and problems that arise when using manual methods can be avoided by using this registration system in terms of cost, time, and resource as well as the security of participant data which is certainly more secure.

\section{LITERATURE REVIEW}

Event is an activity that collects a set of target people in a certain space and time, then a meeting takes place whose message is communicated to those people. The event describes different activities for different purposes [5].

Registration is a process, method, act of registering, recording names, addresses, etc. on the list. Registration is the process of recording the identity of the registrant into a storage media used in the registration process.
Adoption can be defined as the decision to make full use of innovation as the best available action. Whereas adoption of innovation is a process in which an individual switches from first knowledge about innovation to a decision to adopt or reject and to confirm this decision [6]. E-registration is also known as electronic registration or web-based registration or even online registration. This online registration system replaces manual processes such as registering via telephone, mail, or directly at the event using paper forms [7]. In addition, depending on the underlying model, documents can be digitally signed [8].

Event Organizer are parties responsible for managing events such as festivals, social events such as gatherings, meetings, conferences, etc [9].

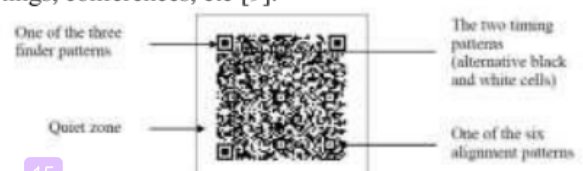

Fig. 1. Example of QR Code $[10]$

The QR Code (Quick Response Code) is a trademark for machine-readable optical labels that contain information about the items attached [11]. The code in the QR Code is a twodimensional barcode. The QR Code was developed by Denso Wave, a Denso Corporation division which was a Japanese company and was published in 1994. QR codes are read with cameras or QR scanners. Figure 1 shows an example of a QR Code.

\section{METHODOLOGY}

The stages of research used in this study shown in Figure

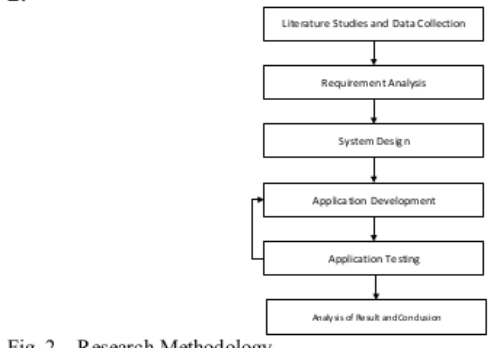

Fig. 2. Research Methodology

\section{1) Literature Studies and Data Collection}

At this stage a study of the Framework Development will be used and data collection. There are two types of data used in this study, namely primary data and secondary data.

a. Primary data

Primary data is obtained from observation, interviews, or questionnaires [12]. In this study the primary data is data relating to the need for registration in an event. To obtain these data, researchers will conduct interviews with event organizers or event organizers and committees on campus

b. Secondary Data

Secondary data is data that already exists, or can be said as data that has been collected and analyzed by other parties. 
Secondary data can be obtained from various sources such as publications, books, magazines, newspapers, reports, recordings and reports on general statistics, etc [12]. To obtain these data the researcher took several books, brochures, websites, and examples of previous research related to this research, namely regarding the flow of registration of participants in an event.

The data collection method used in this study is the Interview method. Interviews are appropriate for cases or questions that require investigation to obtain sufficient information. There are three types of interviews, including: structured, unstructured and semi-structured interviews [13]. The researcher will interview several event organizers and Student Association committees to obtain certain data, especially if the data obtained through the documentation method is unclear.

Population is the term collection to describe the total quantity of an object or case under study. Population can consist of several types of objects, organizations, people, or events [13]. The population used is the party that acts as an event organizer and student committee.

2) Requirement Analysis

In the requirement analysis phase there are primary and secondary data analysis activities, determining system indicators, system indicator analysis, extracting system requirements that are in accordance with the indicators' achievements, and documenting system requirements.

3) System Design

At this stage there are design activities, requirements, process flow, database, applications, and interfaces.

4) Application Development

At this stage an application development is carried out consisting of coding, interface creation, and system installation. The system development method used in this research was FAST method with prototyping as an approach method. FAST is an agile methodology that is flexible enough to support a variety of projects and system development strategies [14]. The letters in FAST stands for "Framework for the Application of the System Thinking". FAST can be said as a best practice from previous methodologies to support the development system and support the system life cycle. FAST method with a prototyping approach chosen based on several considerations:

1. The Prototyping approach involves a lot of users, so it can increase system visibility and get more support from users and management.

2. The Prototyping approach is faster, cheaper, and does not require a large development team. These factors lead to the prototyping approach in accordance with a medium-sized system, such as the system to be developed

3. Prototyping approach can make it easier for users to know their desires. In prototyping, the system consists of several cycles, in which each cycle the team produces a prototype. The results of this evaluation will be analyzed again by the development team and then produce a new prototype. Thus this cycle will continue until the system is obtained in accordance with the wishes of the user. Prototyping cycle shown in Figure 3.

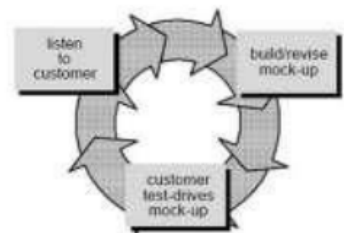

Fig. 3. Prototyping Cycle [15]

\section{5) Application Testing}

After implementation, a system evaluation will be held System evaluation will be carried out at first, second and third year. From this evaluation, results will be obtained which will be used to improve the system every year.

6) Analysis of Results and Conclusions

At this stage, the results of the analysis are carried out and conclusions are drawn.

\section{RESUlt AND Discussion}

Based on the results of observations and interviews with student committees and several event organizers, there were several problems from the participant registration flow to the granting of participant certificates. Figure 4 shows the registration of participants in an event until the acceptance of event certificates by participants using conventional methods.



Fig. 4. Conventional Event Registration Flowchart

Figure 5 shows process flow from participant registration to giving certificates to participants. 


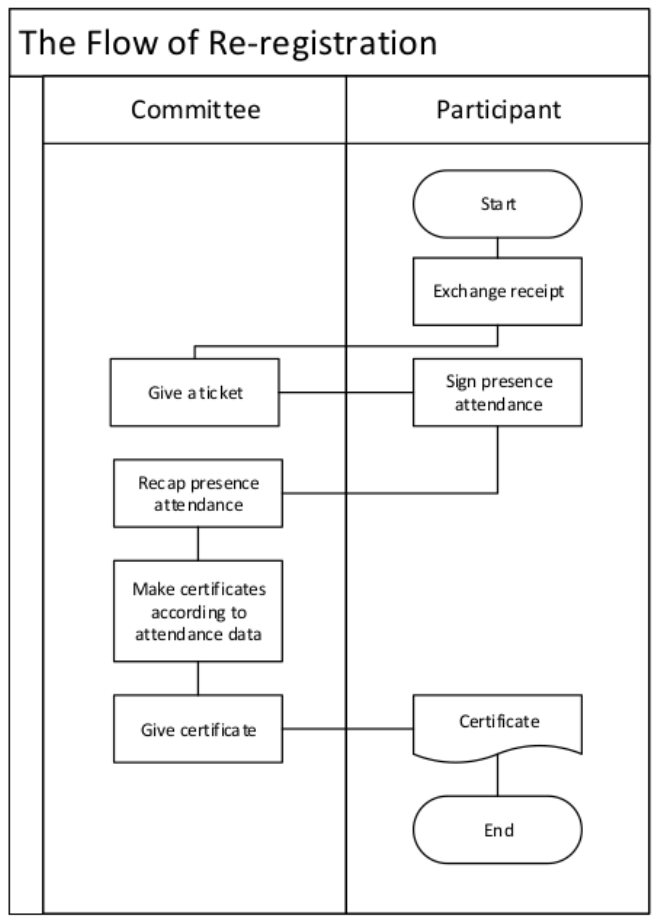

Fig. 5. Conventional Event Re-registration Flowchart

However, conventional registration method has several weaknesses and problems. Analysis of problems that arise from convention method and the solution offered such as:

1. Problem: During registration, Event organizers tend to still use paper as a media for participant registration so that potential participants must come or even queue to register for the event. In addition, the use of paper has the potential to be damaged or lost.

Solution offered: The application of a website-based online event registration system so that prospective participants can register wherever and whenever they are without having to queue. Prospective participants who have registered online through the web will receive e-tickets and $\mathrm{QR}$ codes via email. The event committee also does not need to archive registration paper or form again because all participant registration data has been stored in the system database.

2. Problem: During Re-registration, Event organizers tend to still use paper as a participant registration media, causing participants to come or even queue to enter the location of the event. Again, the use of paper has the potential to be damaged or lost.

Solution Offered: The application of the online event registration system also provides a QRCode Reader feature for event organizers to replace conventional verification methods such as participant presence form using paper. QR codes obtained by participants after registering will be shown to the event committee during the registration process to verify their attendance. With the transition of the registration process from the paper media presence method to attendance verification by scanning the QRcode participant using the QR Code Reader, it is expected that the participants' queuing time and the user of presence attendance paper can be reduced.

3. Problem: For ticketing, events held still tend to use physical tickets which require the committee to issue ticket printing costs. Physical tickets purchased by participants after registration must be taken when attending the event as proof of registration. Such physical tickets have the potential to be lost or damaged so that they can harm participants in terms of material.

Solution offered: The application of an online event registration system provides an e-ticket in which there is also a participant's QR code to replace the physical ticket. The e-ticket was sent to the participant's e-mail according to the e-mail registered. When participants attend the location during the event, Participants only need to show the e-ticket to the event committee. The QR code listed in the e-ticket will be scanned using the mobile app to verify participants' attendance. By utilizing QRCode and its Reader tools, it is expected to reduce physical ticket loss or damage.

4. Problem: In terms of certificate given, current events tend to provide physical certificates for participants as proof of participation. These physical certificates require the committee to spend printing cost. In addition to printing costs, the committee needs to distribute certificates to all attendees after the event ends. This creates a process that is not efficient in terms of time and cost. The committee must look for participant certificates when distributing them, at the same time participants must provide time to queue again after the event ends in order to get a certificate. Solution Offered: The application of an online event registration system provides participant e-certificate features. When the participant's QRcode has been scanned by the committee using a QR Code Reader and its presence has been verified, the participant can download the e-certificate from the website by entering the full name that has been registered and the registrant's ID listed on the e-ticket. With the presence of the e-certificate feature, the committee does not need to share certificates one by one with participants and does not need to pay the cost of printing certificates and participants do not need to queue again to the committee table to obtain certificates.

After analysing problems and offering solution, conventional registration process can be simplified using the help of event 
registration system. The flow of the event registration process that uses QRCode on e-Vent shown in Figure 6.

\section{The Flow of Registration using E-Vent}

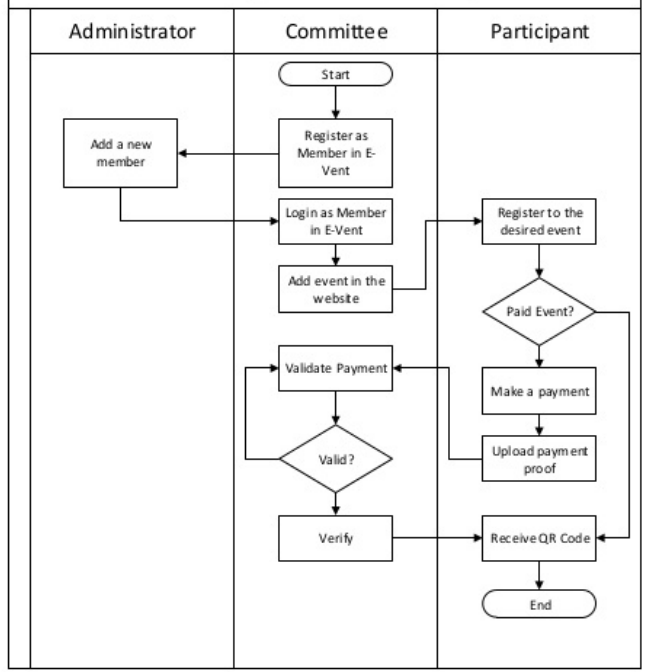

Fig. 6. Event Re-registration using E-Vent Flowchart

Network Architecture of E-vent Registration System shown in Figure 7.

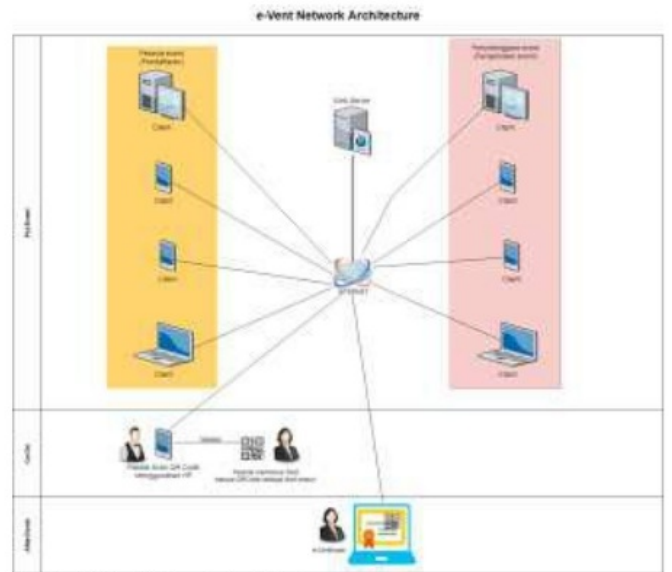

Fig. 7. E-Vent Network Architecture

Based on the solutions mentioned before and e-Vent architecture, the researcher developed a system for managing registration, ticketing, QR code reader \& validation and ecertificate using framework codeIgniter as a backend, ciqrcode library as a QR code generator, MySql for storing databases, and Android Studio for the development of a QR code reader and data validation.
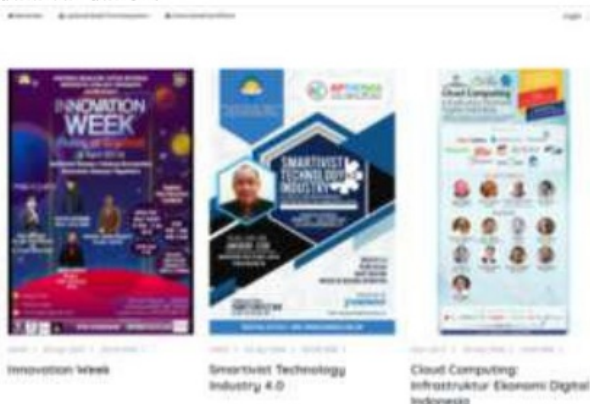

Fig. 8. E-Vent Landing Page

At the landing page shown in Figure 8, the systems will be displayed a list of events held by event organizers who have been registered as members. Prospective participants can choose the event to be attended and see detailed information from the event. In this view there are some general information on the event such as time, place, ticket price, participant quota. Furthermore, prospective participants can immediately register themselves through eventkampus.info prospective participants choose the event they want. The registration form shown in Figure 9.

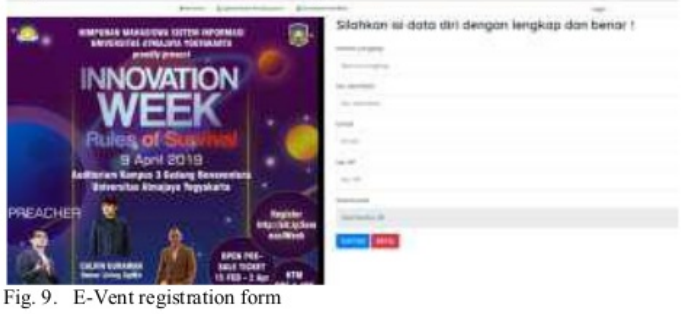

If the event is a paid event, the participants have to make a payment first and then upload proof of payment in the Upload Payment Proof Form shown in Figure 10.

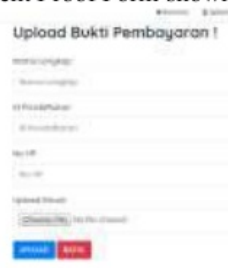

Fig. 10. E-Vent registration form

After the Participant has uploaded proof of payment, proof of payment will be verified by the committee. If verified, the ticket in the form of a QR Code will be sent directly by e-mail to participants. On the ticket there are several information 
such as date, time and place, and there is a QR Code that contains participant data. E-ticket shown in Figure 11.

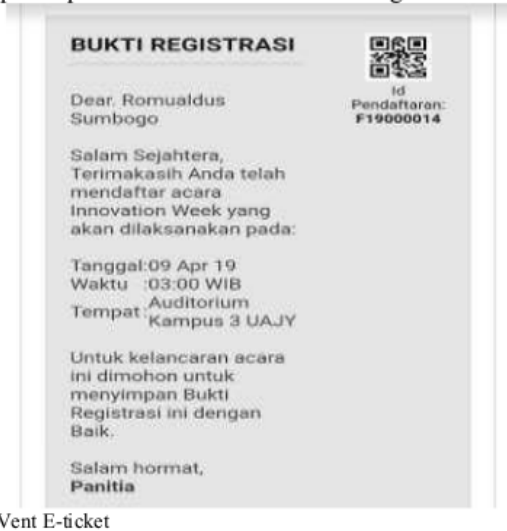

Fig. 11. E-Vent E-ticket

During the day of the event, participants simply show the QR Code shown in E-ticket to be scanned by the committee using mobile apps that function as participant identity validators. The scanning process will change the status of participants in the database from 'not present' to 'attend'. If the event participant's status has been validated, then the event participant will be able to download e-certificate through the "Download Certificate" menu shown in Figure 12.

\section{Download Sertifikat !}

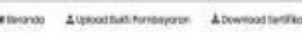

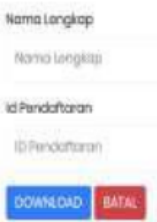

Fig. 12. Download Certificate Menu

\section{CONCLUSION}

Events held in Indonesia tend to apply processes that are still using conventional methods. The conventional method causes some processes to be inefficient in terms of time and cost. Processes that run inefficiently such as the process of registering participants, re-registering participants, ticketing, and giving participant certificates. With the presence of EVent, it is expected to increase efficiency in these processes, especially in the registration process such as the presence of online registration features, e-tickets, QRCodes, and ecertificates. E-Vent offers convenience in managing participant and event data, participant registration, administration and validation, and certificate distribution because it can be done anywhere and anytime.

\section{ACKNOWLEDGMENT}

This research was supported by Lembaga Penelitian dan Pengabdian Masyarakat (LPPM) Universitas Atma Jaya Yogyakarta.

\section{REFERENCES}

[1] S. Mitić, M. Nikolić, J. Jankov, J. Vukonjanski, and E. Terek, "The impact of information technologies on communication satisfaction and organizational learning in companies in Serbia," Comput. Human Behav., vol. 76, pp. 87-101, 2017.

[2] N. I. Jabbouri, R. Siron, I. Zahari, and M. Khalid, "Impact of Information Technology Infrastructure on Innovation Performance: An Empirical Study on private Universities In Iraq," in Procedia Economics and Finance, 2015.

[3] T. Johnson, M. Edinborough, Joshua Binder, A. Bryant, B. Dennis, and E. Al., "Dynamic Registration Forms," in Proceedings of the International Conference on Software Engineering Research and Practice (SERP), 2013.

[4] M. Pérez-Sanagustín, D. Parra, R. Verdugo, G. García-Galleguillos, and M. Nussbaum, "Using QR codes to increase user engagement in museum-like spaces," Comput. Human Behav., 2016.

[5] H. Kose, M. Argan, and M. Argan, "Special Event Management and Event Marketing: A case study of TKBL all star 2011 in Turkey," J. Manag. Mark. Res., 2011.

[6] C. Assumptions and E. M. Rogers, "Diffusion of Innovations Theory," New York Free Press, 2003.

[7] P. Chaka, "An Implimentation Of An Online Based Registration System In Tertiary Institutions In Zimbabwe," Int. J. Eng. Res. Technol., vol. 2, no. 10, 2013.

[8] J. O'Sullivan, "eRegistration and eConveyancing in Ireland - the story so far," in Registering the World Conference Dublin, 2007.

[9] A. Saleem, D. A. Bhat, and O. F. Khan, "Review Paper on an Event Management System," Int. J. Comput. Sci.Mob. Comput., vol. 6, no. 7, 2017.

[10] C. Law and S. So, "QR Codes in Education," J. Educ. Technol. Dev. Exch., 2010.

[11] E. Ozkaya, H. E. Ozkaya, J. Roxas, F. Bryant, and D. Whitson, "Factors affecting consumer usage of QR codes," J. Direct, Data Digit. Mark. Pract., 2015.

[12] C. Kothari, Research Methodology: Methods and Techniques. 2004.

[13] N. Walliman, Research Methods The Basics. New York: Taylor \& Francis, 2011.

[14] J. L. Whitten and Lonnie D. Bentley, Systems Analysis and Design Methods. 2007.

[15] R. S. Pressman, Software Engineering A Practitioner's Approach 7th Ed - Roger S. Pressman. 2009. 


\section{icaiti}

ORIGINALITY REPORT

$8 \%$

SIMILARITY INDEX
$4 \%$

INTERNET SOURCES
$4 \%$

PUBLICATIONS
$6 \%$

STUDENT PAPERS

PRIMARY SOURCES

1 Submitted to Universitas Atma Jaya Yogyakarta Student Paper

2 N Rochmawati, I G P A Buditjahjanto, R E

Putra, A Y Wicaksono. "A Responsive Web-

Based QR Code for Inventory in The Laboratory

of Informatics, UNESA", IOP Conference Series:

Materials Science and Engineering, 2018

Publication

3

Submitted to HELP UNIVERSITY

Student Paper

4 Submitted to University of College Cork Student Paper

5 es.scribd.com Internet Source

Clara Hetty Primasari, Djoko Budiyanto Setyohadi. "Improvement of Information

Technology Infrastructure in Higher Education

using IT Balanced Scorecard", 2018 5th

International Conference on Electrical 
Engineering, Computer Science and Informatics (EECSI), 2018

Publication

7 Submitted to Federal University of Technology Student Paper

8 Jason Moats. "chapter 13 Influences on the Acceptance of Innovative Technologies Used in Learning Opportunities", IGI Global, 2015

Publication

9 link.springer.com Internet Source

10 e-journal.uajy.ac.id Internet Source

11 docplayer.net

13 Yue Liu, Mingjun Liu. "Automatic Recognition Algorithm of Quick Response Code Based on Embedded System", Sixth International Conference on Intelligent Systems Design and Applications, 2006 Publication

"Advances in Ergonomics of Manufacturing: Managing the Enterprise of the Future", 
Springer Science and Business Media LLC,

2016

Publication

15

Jantana Panyavaraporn, Paramate Horkaew, Wannaree Wongtrairat. "QR code watermarking

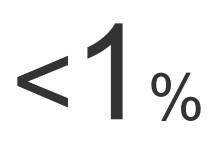
algorithm based on wavelet transform", 2013 13th International Symposium on Communications and Information Technologies (ISCIT), 2013

\author{
Publication
}




\section{icaiti}

GRADEMARK REPORT

FINAL GRADE

10

PAGE 1

PAGE 2

PAGE 3

PAGE 4

PAGE 6

\section{PAGE 5}

GENERAL COMMENTS

Instructor 